\title{
STRATEGI KOMUNIKASI PARIWISATA HALALSTUDI KASUS IMPLEMENTASI HALAL HOTEL DI INDONESIA DAN THAILAND
}

\author{
${ }^{1}$ Atie Rachmiatie, ${ }^{2}$ Rahma Fitria, ${ }^{3}$ Karim Suryadi, ${ }^{4}$ Rahmat Ceha \\ ${ }^{1234}$ Universitas Islam Bandung \\ Jalan Taman Sari No 1 Bandung \\ lppmunisbamdy@gmail.com
}

\begin{abstract}
Abstrak
Indonesia menempati rangking pertama pada sepuluh destinasi favorit untuk liburan, dengan indeks 78 pada GMTI 2019. Pemerintah gencar mencanangkan pengembangan pariwisata halal. Namun perkembangan Hotel Halal di Indonesia tidak semarak di Thailand, yang diduga ada permasalahan komunikasi antara pemerintah dengan industri.Tujuan penelitian mengkaji strategi komunikasi yang efektif dalam mensosialisasikan konsep hotel halal. Metode kualitatif pendekatan studi kasus, dan teknik purposive sampling. Penelitian menunjukkan bahwa komunikasi dari pemerintah penting dalam memperkuat persepsi tentang product value dan benefit dari pariwisata halal. Latar belakang ada hotel halal karena faktor intrinsic yaitu agama dari pemilik dan exstrinsic yaitu, permintaan wisatawan dan biaya. Perbedaan perkembangan hotel halal, di Bangkok minat wisatawan muslim sangat tinggi, sehingga inisiatif datang dari pengusaha,sedangkan di Bandung, standar dasar halal dianggap sudah menyatu dalam kehidupan masyarakat, sehingga tidak urgent untuk menerapkan "branding" hotel halal. Untuk itu Model strategi komunikasi pariwisata efektif diperlukan pemerintah dalam pengembangan wisata halal.
\end{abstract}

Kata Kunci : Strategi komunikasi, Pariwisata halal, Product Value, Industri Hotel

\begin{abstract}
Abstrack
Indonesia ranks first in ten favorite destinations for holidays, with an index of 78 in GMTI 2019. The government is aggressively launching the development of halal tourism. However, the development of Halal Hotels in Indonesia is not vibrant in Thailand, which is suspected to have communication problems between the government and the industry. The purpose of the study is to examine effective communication strategies in socializing the concept of halal hotel. The qualitative method uses a case study approach and purposive sampling technique. Research shows that communication from the government is important in strengthening perceptions about product value and benefits of halal tourism. The background is that there are halal hotels because of intrinsic factors namely the religion of the owner and exstrinsic namely, tourist demand and cost. The difference in the development of halal hotels, in Bangkok the interest of Muslim tourists is very high, so the initiative came from businessmen, whereas in Bandung, basic halal standards are considered to be integrated in people's lives, so it is not urgent to implement halal hotel "branding". For this reason, an effective tourism communication strategy model is needed by the government in developing halal tourism.
\end{abstract}

Received: 2019-11-20 | Reviced: 2020-01-30 | Accepted: 2020-01-31

Indexed : Sinta, DOAJ, Garuda, Crossref, Google Scholar |

DOI: https://doi.org/10.29313/amwaluna.v4i1.5256 
Atie Rahmiatie, Rahma Fitria, Karim Suryadi, Rahmat Ceha, Strategi Komunikasi Pariwisata Halal...

Keywords: Communication strategies, Halal tourism, Product Value, Hotel Industry

\section{Pendahuluan}

Saat ini Indonesia menempati rangking pertama pada sepuluh destinasi favorit untuk liburan (top ten holiday destinations), dengan indeks 78 pada GMTI 2019. Indonesia dinilai mampu mengembangkan pariwisata yang sesuai dengan kebutuhan wisatawan muslim yang dikenal lebih spesifik dibanding kebutuhan wisatawan pada umumnya. Pemerintah Indonesia pun gencar melakukan berbagai strategi pengembangan pariwisata halal. Namun demikian perkembangan Hotel Halal di Indonesia tidak semarak di Malaysia, bahkan Thailand. Respon industri perhotelan khususnya tidak sebanding dengan prestasi yang diraih oleh pemerintah Indonesia. Sehingga diduga ada permasalahan komunikasi antara pemerintah dengan industri.

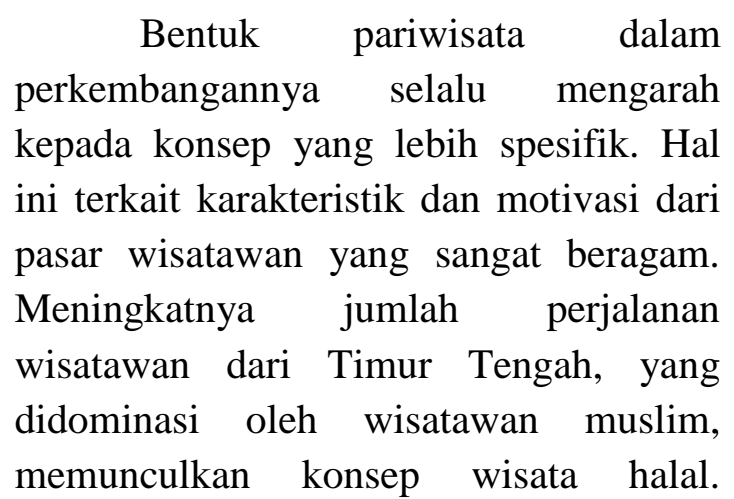
Konsep ini memunculkan perjalanan wisata yang tidak menurunkan kualitas keimanan, memudahkan dalam menjalankan kewajiban agama dan sesuai dengan ketentuan agama Islam. Kebutuhan yang lebih spesifik tersebut terkait dengan ketentuan dalam agama Islam yang menyatakan bahwa setiap tindakan adalah ibadah, sehingga dalam berwisata pun, tetap harus melakukan beberapa ketentuan wajib yang tidak boleh ditinggalkan. Kebutuhan ini yang membedakannya dengan bentuk wisata pada umumnya (Andriani, 2015). Menurut Mastercard, 2016 terdapat empat kebutuhan khas wisatawan muslim yang tidak terdapat pada wisatawan pada umumnya, yaitu 1) kebutuhan untuk bersuci pada saat hendak shalat, 2) kebutuhan sarana dan prasarana ibadah sholat, 3) kebutuhan akan makanan yang terjamin kehalalannya dan 4) kebutuhan untuk mengikuti dan menikmati atraksi wisata yang tidak bertentangan dengan nilai-nilai Islam selama melakukan kegiatan wisata.

Di Indonesia, apa yang kemudian disebut wisata halal dikenal dengan beberapa istilah. Pada awalnya dikenal istilah wisata religi, sesuai dengan perkembangan global (Raj \& Griffin, 2015), namun kemudian dikenal juga istilah wisata rohani khusus untuk kegiatan wisata keagamaan bagi wisatawan non muslim (Sucipto \& Andayani, 2014). Kemudian muncul istilah wisata syariah (syaria). Istilah syariah semula dinilai lebih tepat karena menunjukkan implementasi nilai-nilai syariah Islam (Sucipto \& Andayani, 2014), bahkan sempat menjadi terminologi resmi Kementrian Pariwisata pada tahun 2011 (Nirwandar, 2012), namun belakangan menuai pertanyaan dan kritik. Istilah syariah dinilai kurang bisa diterima secara umum dan sangat eksklusif, sehingga digunakan istilah pariwisata halal, yang menjadi populer hingga saat ini (Andriani et al., 2015). 
Perkembangan pariwisata halal di Indonesia juga didukung oleh berbagai kebijakan pemerintah, baik langsung maupun tidak langsung. Dukungan pemerintah terhadap wisata halal ditandai dengan terbitnya Undang-undang No. 33 tahun 2014 terkait kewajiban pemerintah dalam memberikan jaminan kepada konsumen tentang produk yang beredar di pasaran. Dalam undang-undang tersebut juga diamanatkan tentang pembentukan Badan Pusat Jaminan Produk Halal (BPJPH). Implementasi konsep wisata halal secara lebih rinci tertuang di dalam Peraturan Menteri Pariwisata dan Ekonomi Kreatif No.2 tahun 2014 tentang Pedoman Penyelenggaraan Usaha Hotel Syariah, yang mengatur standard dan kriteria penyelenggaraan usaha akomodasi berlabel syariah. Di dalamnya antara lain diatur penggolongan hotel syariah ke dalam dua kategori, yaitu Hotel Syariah Hilal 1 dan Hilal 2. Hotel syariah Hilal 1 adalah hotel yang dianggap telah memenuhi standar minimal kriteria hotel syariah berdasarkan kebutuhan wisatawan muslim. Sementara standar Hilal 2 merupakan hotel yang telah memenuhi seluruh ketentuan standar hotel syariah yang terdapat dalam peraturan tersebut.

Kesiapan destinasi halal dapat dilihat dari tiga aspek, yaitu produk, sumber daya manusia (SDM) dan kelembagaan, serta promosi (Andriani et al., 2015). Pada tahun 2017 Pemerintah menetapkan 10 destinasi halal di seluruh Indonesia. Kesepuluh destinasi tersebut tersebar di seluruh wilayah Indonesia. Tiga di antara 10 destinasi tersebut menjadi destinasi halal prioritas, yaitu Aceh, Sumatera Barat dan Nusa Tenggara Barat (NTB). Selain tiga destinasi utama tersebut, Makassar dan Jawa Barat bergabung menjadi lima destinasi utama. Di samping lima besar tersebut, destinasi wisata halal lainnya adalah DKI Jakarta, Kepulauan Riau (Batam), DIY, Jawa Timur dan Jawa Tengah.

Destinasi halal di Indonesia memiliki potensi pasar yang besar. Di dalam negeri sendiri terdapat 250 juta umat Muslim, yang memerlukan terpenuhinya empat kebutuhan wisatawan Muslim. Apabila diproyeksikan pada tahun 2019 terjadi 242 juta perjalanan, peluang ini pun menjadi semakin besar.

Rendahnya sosialisasi sertifikasi hotel syariah dinilai sebagai suatu sebab masih rendahnya minat industri wisata di Indonesia dalam mengimplementasikan konsep wisata halal. Saat ini perkembangan wisata halal di negara ASEAN, baik dari negara yang didominasi oleh penduduk muslim maupun non muslim, masih menunjukkan perkembangan yang lebih tinggi dibanding Indonesia. Berikut ini merupakan gambaran perkembangan wisata halal di beberapa negara ASEAN pada tahun 2013.

Tabel 1. Perbandingan Praktek Wisata Halal pada Tahun 2013

\begin{tabular}{|l|l|l|l|l|}
\hline & Indonesia & Singapura & Malaysia & Thailand \\
\hline Total wisman & 8.802 .129 & 15.567 .923 & 25.715 .460 & 26.546 .725 \\
\hline $\begin{array}{l}\text { Wisman } \\
\text { muslim }\end{array}$ & 1.729 .912 & 3.920 .907 & 6.099 .279 & 4.419 .310 \\
\hline \% & $20 \%$ & $25 \%$ & $24 \%$ & $17 \%$ \\
\hline Implementasi & - Hotel syariah & - Hotel dan & -Hotel syariah & -Hotel dan \\
\hline
\end{tabular}




\begin{tabular}{|c|c|c|c|c|}
\hline $\begin{array}{l}\text { wisata } \\
\text { syariah }\end{array}$ & $\begin{array}{l}\text { bersertifikat: } \\
12 \text { hotel } \\
\text { - Hotel dengan } \\
\text { resto halal } \\
\text { bersertifikat : } \\
25 \\
\text { Restoran } \\
\text { bersertifikat } \\
\text { halal : } 305 \\
\text {-Travel syariah } \\
\text { bersertifikat : } 1\end{array}$ & $\begin{array}{l}\text { restoran } \\
\text { bersertifikat } \\
\text { halal : } 2.691 \\
\text { - Memiliki } \\
\text { AMTAS } \\
\text { (Association } \\
\text { of Muslim } \\
\text { Travel Agent } \\
\text { of Singapore) }\end{array}$ & $\begin{array}{l}\text { bersertifikat: } \\
\text { 366. (273 } \\
\text { adalah hotel } \\
\text { bntang 3-5) } \\
\text {-Restoran } \\
\text { bersertifikat } \\
\text { halal +2000 } \\
\text { - The top } \\
\text { destination } \\
\text { for muslim } \\
\text { tourist 2011, } \\
\text { 2012, } 2013 \\
\text { dan } 2014 \\
\text {-KLIS terpilih } \\
\text { sebagai the } \\
\text { most muslim } \\
\text { friendly } \\
\text { airport in the } \\
\text { world }\end{array}$ & $\begin{array}{l}\text { restorer } \\
\text { bersertifikat } \\
\text { halal : }+100 \\
\text { - Memiliki halal } \\
\text { science center } \\
\text { yang } \\
\text { mendukung } \\
\text { Thailand } \\
\text { sebagai } \\
\text { produsen dan } \\
\text { eksportir } \\
\text { produk halal } \\
\text { terbesar di } \\
\text { Asia } \\
\text { - Bandara } \\
\text { internasional } \\
\text { Suwarnabhum } \\
\text { i adalah } \\
\text { bandara non } \\
\text { muslim yang } \\
\text { paling muslim } \\
\text { friendly }\end{array}$ \\
\hline
\end{tabular}

Sumber : Andriani (2015)

Tingginya animo masyarakat terhadap wisata halal di satu sisi dan rendahnya respon industri di tanah air merupakan masalah yang menarik dikaji dari perspektif komunikasi. Kesenjangan tadi menunjukan perbedaan persepsi tentang wisata halal, sekaligus mengisyaratkan adanya hambatan komunikasi antara pemerintah dan stakeholders pariwisata. Tren wisata halal dunia, belum sejalan dengan respon industri di Indonesia dalam mengimplementasikan konsep wisata halal di Indonesia. Jumlah penduduk muslim yang tinggi seharusnya menjadi peluang besar bagi tumbuhnya wisata halal di Indonesia. Sebagai salah satu produk dari wisata halal, hotel syariah di Indonesia jumlahnya masih jauh lebih sedikit dari hotel konvensional, padahal pemerintah melalui Kementrian Pariwisata telah memfasilitasi kebijakan hotel syariah serta sertifikasinya melalui MUI. Pemerintah sebagai regulator memiliki kewajiban untuk mensosialisasikan benefit hotel syariah ini kepada masyarakat umum. Selama manfaat ini belum dirasakan maksimal oleh masyarakat, maka minat untuk memilih dan mengimplementasikan hotel syariah akan rendah.

Kebijakan mengenai standar kriteria hotel syariah dapat dijadikan sebagai acuan dalam mengidentifikasi gap antara persepsi industri dengan wisatawan mengenai konsep wisata halal. Thalib, et.al, (2015) dalam penelitiannya menemukan bahwa setidaknya terdap empat gap sebagai penyebab terhambatnya operasionalisasi konsep halal dalam industri pariwisata. Keempat gap tersebut adalah internal barriers, inter firm barriers, firm-government barriers and firm-authority barriers. 
Penelitian ini mengkaji tentang komunikasi dan penyebaran informasi khususnya dari pemerintah tentang konsep hotel syariah. Analisa ini bermanfaat untuk menjembatani kesenjangan antara minat masyarakat terhadap wisata halal dengan rendahnya respon industri di Indonesia. Pilihan bentuk komunikasi, informasi, dan edukasi tentang wisata halal akan menentukan respon industri dalam menerapkan standar hotel syariah dalam pengelolaan dan kegiatan operasionalnya. Lebih dari itu, strategi ini pun dapat meningkatkan minat wisatawan untuk memilih hotel syariah sebagai produk wisata yang aman, nyaman dan menyenangkan.

Secara teoretis, penelitian ini akan memberikan kontribusi terhadap model komunikasi pariwisata, khususnya komunikasi massa dan komunikasi publik, seperti promosi, sosialisasi, kampanye dalam rangka membangun pemahaman, kesadaran, kepercayaan, dan kerjasama dari masyarakat luas. (Kim, 2007). Secara teoritis (Sweeney \& Soutar, 2001) minat individu dipengaruhi oleh persepsinya, dan komunikasi merupakan salah satu faktor yang mempengaruhi persepsi seseorang. Sehingga penelitian ini tahap awal menganalisa bagaimana komunikasi pariwisata yang disampaikan oleh pemerintah selama ini berkaitan dengan persepsi dan minat wisatawan terhadap konsep hotel syariah. Oleh karena pemerintah sebagai regulator memiliki kewajiban untuk menjembatani demand dan supply agar selaras. Melalui Model strategi komunikasi yang efektif kepada masyarakat dan industri, peningkatan minat dapat tercapai, sehingga implementasi konsep hotel syariah dapat terwujud. Permasalahan penelitian dirinci pada : Bagaimana persepsi dan minat industri hotel terhadap konsep hotel syariah? Mengapa industri hotel belum optimal mengimplementasikan konsep syariah dan apa faktor penghambatnya ? Serta Bagaimana strategi komunikasi yang harus dilakukan pemerintah dalam menstimulasi wisatawan dan industri agar memiliki minat yang tinggi terhadap hotel syariah? Urgensi penelitian ini menghasilkan model strategi komunikasi pemerintahan di bidang pariwisata yang efektif untuk menyamakan persepsi tentang benefit wisata halal bagi industri dan wisatawan. Di samping memperkuat peran informasi pemerintah dalam menjembatani kebutuhan antara wisatawan muslim dengan industri perhotelan.

\section{Pembahasan}

Wisatawan muslim adalah individu yang melakukan aktivitas wisata dengan latar belakang beragama Islam. Setiap wisatawan memiliki persepsi dan preferensi tersendiri dalam pemilihan dan penentuan aktivitas wisata, begitupun juga dengan wisatawan muslim dimana memiliki kewajiban yang harus dipenuhi dalam menjalankan aturan agamanya.

Persepsi dan preferensi wisatawan memiliki peranan yang penting dalam pemilihan suatu destinasi ataupun atraksi wisata. Persepsi wisatawan yang akan melakukan aktivitas wisata, timbul setelah mereka menggali informasi mengenai objek wisata yang akan dikunjunginya dari berbagai sumber. Hal ini menjadi sangat peting dilakukan, terutama oleh wisatawan muslim untuk mendapatkan informasi yang 
tepat tentang objek wisata dan kesesuaian dengan apa yang ingin ditemukannya dari objek wisata yang akan ditujunya. Sementara preferensi wisatawan dapat berarti kesukaan, pilihan atau sesuatu hal yang lebih disukai wisatawan, dimana preferensi ini terbentuk dari persepsi wisatawan (Eid, 2013). Preferensi menunjukkan pilihan suka atau tidak suka wisatawan atau selera terhadap produk (barang atau jasa) wisata yang ditawarkan oleh suatu destinasi wisata.

Persepsi wisatawan dapat terbentuk melalui berbagai cara, yaitu melalui informasi atau stimulus yang langsung diterima oleh indera penglihatan,pendengaran, pembauan, pencicipan, dan perasa. Sumber persepsi yang diterima secara tidak langsung diantaranya dari media informasi dan komunikasi yang digunakan oleh siapapun yang menyampaikan pesannya. Persepsi wisatawan menjadi hal penting dalam memutuskan destinasi mana yang akan dipilih oleh wisatawan, karena persepsi seseorang sangat dipengaruhi oleh karakteristik pribadinya, motif, minat, pengalaman masa lampau serta ekspektasi yang diterima melalui panca indera (Stephen \& Robbins, 2015). Hasil dari persepsi awal inilah yang akan sangat besar mempengaruhi keputusan wisatan dalam berwisata.

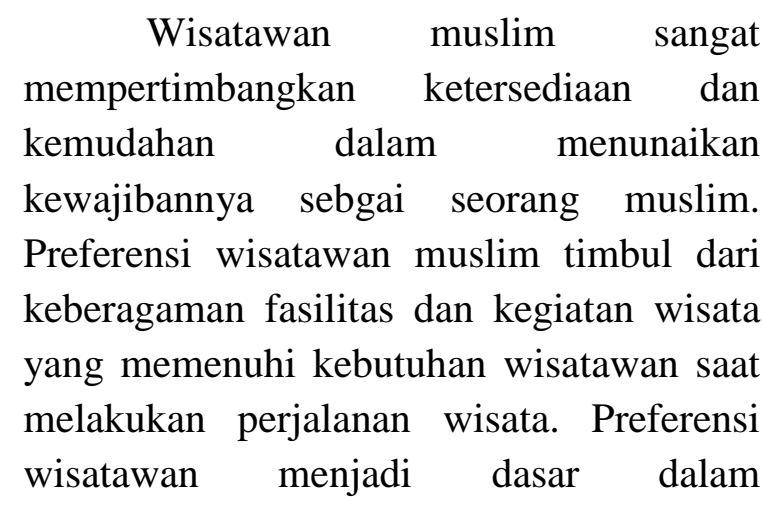

memperhitungkan keinginan dan kebutuhan akan pelayanan fasilitas wisata yang akan diterima. Pertimbangan ini akan memberikan respon berupa persepsi baik positif maupun negatif terhada destinasi wisata yang akan ditujunya. Persepsi positif akan mendorong seseorang untuk membeli produk, sedangkan persepsi negatif akan mendorong seseorang untuk tidak membeli produk. Untuk menciptakan persepsi yang positif, maka suatu objek wisata dituntut untuk memenuhi keinginan wisatawan (Pitana, 2005).

Penelitian Chen, Chen Lee menemukana bahwa, Persepsi wisatawan muslim ini harus menjadi salah satu pertimbangan penting dalam pengembangan suatu destinasi wisata, mengingat besarnya potensi wisatawan muslim dalam perkembangan pariwisata dewasa ini. Hal ini dikarenakan persepsi dari setiap individu wisatawan muslim dapat diterjemahkan menjadi persepsi kolektif yang dapat memberikan masukan dan membuat destinasi wisata menjadi lebih bersaing dan meningkatkan interaksi berulang wisatawan terhadap destinasi wisatawan tersebut (Chen, Chen, Lee, \& Tsai, 2016; Harrigan, Evers, Miles, \& Daly, 2017).

Beberapa penelitian juga menemukan bahwa, konsep halal dapat diterima oleh semua kalangan termasuk non muslim, karena dikenal menghasilkan produk yang aman, sehat dan baik (Ambali and Bakar, 2013; Wilson and Liu, 2010). Mengacu kepada fakta yang disebut terakhir, menjadi kurang beralasan jika menganggap wisata halal sebagai bentuk wisata eksklusif. Dari sisi wisatawan, berwisata merupakan kegiatan menyenangkan, dengan motivasi untuk 
mencari kesenangan dan relaksasi selain keamanan dan kenyamanan ketika melakukan wisata. Standar pariwisata halal seperti apa yang sesungguhnya diharapkan oleh wisatawan perlu terus dikaji. Apa yang sebetulnya mereka inginkan terkait standar kenyamanan, keamanan dan kepuasan wisatawan muslim terhadap aspek produk, pelayanan dan pengelolaannya. Bagi industri, informasi ini sangat penting, karena memberikan gambaran dalam mengembangkan konsep halal, khususnya untuk mengimplementasikan standar hotel syariah, sesuai dengan ketentuan yang ditetapkan pemerintah.

Selanjutnya persepsi industri akan terkait dengan potensi dan kendala/hambatan dalam mengimplementasikan standar hotel syariah. Sebagai otoritas yang melegalkan konsep wisata halal, pemerintah Indonesia memiliki peran penting dalam mengkomunikasikan konsep halal kepada masyarakat luas dan industri, agar keberterimaannya terus meningkat (Kim, 2007). Pengertian wisata dalam undangundang kepariwisataan menyatakan bahwa, wisata adalah kegiatan perjalanan yang dilakukan oleh seseorang atau sekelompok orang dengan mengunjungi tempat tertentu untuk tujuan rekreasi, pengembangan pribadi, atau mempelajari keunikan daya tarik wisata yang dikunjungi dalam jangka waktu sementara (Undang-undang No 10 Tahun 2009 Tentang Kepariwisataan). Dalam pandangan Islam, Pariwisata diwujudkan dalam hal perjalanan spiritual, tentang pemaknaan dan pencapaian sebuah tuntutan ajaran agama itu sendiri "syahriah" dan yang berhubungan dengan spritualitas tentang kebesaran ciptaan Tuhan (Dallen, 2013; Results et al., 2015). Dalam pelaksanannya, aktivitas wisata ini dikemas dengan istilah wisata halal.

Persepsi wisatawan global tentang wisata halal terus meningkat secara positif. Penelitian Syakiry dan Suherlan menyatakan bahwa : Produk wisata halal akan memberikan kenyamanan bagi siapapun wisatawan sekalipun non muslim. Konsep wisata halal ini memberikan perlindungan dan jaminan kepada konsumen terhadap produk wisata yang ditawarkan, dengan demikian wisata halal mudah diterima oleh seluruh wisatawan. (Shakiry, 2009)

Wisata halal sebagai konsep baru dalam dunia pariwisata yang mengangkat nilai religius dan menyesuaikan kebutuhan wisatawan muslim yang mematuhi aturan syariah. (Bozorgaghideh, 2015). Wisata halal memiliki potensi yang sangat besar untuk menambah pendapatan suatu negara. Akyol dalam penelitiannya menyatakan bahwa wisatawan Muslim menghabiskan 102 miliar Euro di 2011, diharapkan pada 2020 jumlah ini akan mencapai 158 miliar Euro, dimana keyakinan agama sangat mempengaruhi perjalanan wisatawan muslim (Akyol, 2014). Hal ini didukung oleh laporan dari Amadeus Traveller Trend Observatory (ATTO) tentang Halal Travellers 2016 yang menyatakan bahwa wisata halal akan tumbuh sebesar $50 \%$ (volume) dan 35\% (nilai) dalam 5 tahun ke depan hal ini dikarenakan pertumbuhan populasi muslim akan terus berlanjut dan meningkat sehingga wisatawan muslim diperkirakan akan tumbuh dari 110 juta sampai 150 juta pengunjung pada 2020, yang pada akhirnya kondisi ini akan mewakili $11 \%$ pasar dengan pengeluaran yang diproyeksikan akan tumbuh menjadi \$ 200 miliar (Amadeus Traveller Trend 
Observatory, 2016). Angka yang sangat besar jika dapat dikelaola dengan baik untuk pendapatan negara. Hal inimenyebabkan negara-negara di dunia mulai mengembangkan konsep wisata halal, baik memiliki destinasi yang berkaitan dengan wisatawan muslim maupun tidak.

Kajian Andriani menemukan bahwa, di beberapa Negara yang menerapkan wisata halal menggunakan istilah yang berbeda-beda seperti Islamic tourism, halal tourism, halal travel, ataupun as moslem friendly destination (Andriani et al., 2015). Negara-negara di dunia yang sudah mengembangkan konsep wisata halal, diantaranya adalah Turki, Jepang, Malaysia, Thailand dan Indonesia.

Motivasi wisatawan untuk berwisata selain mendapatkan pengalaman baru, juga berharap mendapat rasa aman dalam berwisata. Kenyamanan dan kemanan sama pentingnya dengan fasilitas infrastruktur dan promosi untuk perjalanan dan pariwisata juga ( Ayob \& Masron, 2014) sehingga harus mendapat perhatian khusus dari pengelola objek wisata maupun dari pemerintah sebagai regulator wisata nasional. Peran negara dalam hal ini adalah pemerintah, selain menjamin keamanan nasional dan stabilitas politik, pemerintah juga harus memberikan perlindungan terhadap wisatawan (Pandian, 2013). Perlindungan ini bisa berupa perlindungan terhadap wisatawan yang datang maupun wisatawan yang keluar negeri berupa travel warning.

Faktor kenyamanan dan keamanan pada suatu kawasan pariwisata merupakan nilai tambah dan perluang untuk dikunjungi oleh wisatawan. Kondisi ini dipengaruhi dan disebabkan oleh beragam faktor, seperti kondisi politik di daerah tujuan wisata, konflik lokal, bencana alam, perilaku sosial masyarakat. Bagi wisatawan muslim selain faktor -faktor tersebut, nilai dan tradisi Islam, termasuk makanan halal dan kenyamanan dalam praktik keagamaan menjadi salah satu pertimbangan bagi wisatawan Muslim (Iravani \& Mozaffari, 2013).

\section{Hambatan dalam Implementasi Produk Wisata Halal}

Dalam beberapa penelitian, tercatat adanya beberapa hal yang menghambat pertumbuhan dan perkembangan pasar wisata halal. Salah satu penyebabnya adalah inkonsistensi definisi halal, permasalahan logo halal, antipati terhadap istilah yang berkaitan dengan Arab atau Islam serta rendahnya dukungan dari lembaga halal yang ada (Shafie dan Othman, 2006). Thalib (2015) melakukan penelitian mengenai hambatan dalam operasionalisasi logistik produk halal. Hasilnya menunjukan bahwa hambatan operasional dapat dikelompokkan menjadi faktor internal yang terkait dengan aspek pendanaan, rendahnya keinginan untuk menggunakan konsep halal serta masih belum memadainya sarana prasarana terkait standar halal yang sesuai. Selain itu, terdapat hambatan eksternal yang terdiri dari hambatan antara sesama industri (persaingan yang tidak sehat), kebijakan pemerintah yang kurang mendukung dan hambatan teknis dari badan otoritas. Walaupun penelitian ini berkaitan langsung dengan aspek logistik produk halal, namun terdapat garis merah yang bisa dijadikan acuan yang sama dengan produk pelayanan wisata halal, yaitu : 
- Rendahnya kolaborasi antar industri dalam implementasi konsep halal

- Isu standarisasi yang belum bisa diterima semua kalangan industry

- Rendahnya sosialisasi wisata halal dari pemerintah

- Ketatnya standar halal yang dikeluarkan badan otoritas halal

- Mahal dan lamanya waktu pengajuan sertifikasi produk halal

- Aspek hambatan komunikasi dari badan otoritas kepada industri. (observasi peneliti, 2018)

\section{Strategi Komunikasi Efektif}

Komunikasi sebagai bentuk penyampaian informasi merupakan hal yang sangat penting didalam organisasi. Namun demikian terdapat beberapa hambatan di dalam komunikasi, sehingga tujuan yang ingin dicapai tidak sesuai dengan yang diharapkan. Hambatan dalam komunikasi diantaranya, hambatan fisik, hambatan psikologis, hambatan organisasi dan hambatan bahasa. Dalam mengatasi hambatan komunikasi ini, maka strategi komunikasi dibutuhkan sebagai bentuk perencanaan untuk menyampaikan informasi. Strategi komunikasi ini merupakan bentuk komunikasi yang memiliki tujuan khusus sehingga organisasi dapat memenuhi misinya (Hallahan et al., 2007), sehingga digunakan sebagai landasan dalam menentukan program dan aktivitas komunikasi yang sesuai dengan tujuan yang ingin dicapai (Holtshausen \& Zerfass, 2015).

Salah satu kajian mengenai strategi komunikasi yang penting untuk diteliti adalah terkait komunikasi eksternal, antara organisasi dengan stakeholder yang berkaitan seperti konsumen, lembaga terkait dan masyarakat umum. Strategi komunikasi ini dapat berfungsi sebagai jembatan (bridge) untuk menghubungkan organisasi dengan stakeholder atau penyangga (buffering) bagi organisasi, untuk menjaga posisi dan reputasi lembaga (Wonneberger, 2016). Media komunikasinya pun sangat beragam, seperti surat kabar, media masa dan media sosial. Strategi kumunikasi juga memiliki fungsi sebagai jembatan antara organisasi dengan eksternal stakeholder.

Berkaitan dengan gap komunikasi dalam sosialisasi konsep wisata halal dan standar hotel syariah, perlu dipahami bahwa hal ini berkaitan dengan fungsi komunikasi sebagai penghubung/ jembatan antara pemerintah sebagai lembaga yang mengeluarkan kebijakan standar hotel syariah dan produk halal, dengan stakeholder yaitu industri dan wisatawan. Konsep ini sejalan dengan fungsi komunikasi eksternal yang difokuskan pada relasi yang saling terikat (mutually dependent relationship) antara lembaga dengan beragam stakeholder (Cancel et al, 1997). Menurut Wonneberger (2016), terdapat 2 jenis strategi komunikasi eksternal yaitu komunikasi dua arah (twoway) dan komunikasi simetris (symmetrical). Komunikasi 2 arah lebih mempertimbangkan opini stakeholder dan pertukaran informasi secara lebih intensif, sehingga perkembangan lembaga lebih dinamis. Sedangkan dalam komunikasi simetris, lembaga menentukan kebijakannya sendiri setelah mendapat masukan dari stakeholder.

Dalam konteks perubahan minat wisatawan dan sikap industri terhadap hotel syariah studi komunikasi merekomendasikan pentingnya mempertimbangkan aspek-aspek yang turut membantu perubahan sikap. Aspek 
Atie Rahmiatie, Rahma Fitria, Karim Suryadi, Rahmat Ceha, Strategi Komunikasi Pariwisata Halal...

dimaksud oleh Krech, Crutchfield \& Ballachey (1962: 225) dirumuskan dalam sebuah dalil :

"Attitude change is brought about through exposure to additional information, changes in the group affiliations of the individual, enforced modification of behavior toward the object, and through procedures which change personality".

Penelitian ini difokuskan kepada persepsi pengelola industri hotel tentang wisata halal dan penerapan standar hotel syariah. Mengingat secara yuridis aturan tentang standar hotel syariah telah tersedia, maka penelitianini juga fokus pada kendala-kendala komunikasi yang diduga menyebabkan kesenjangan antara minat wisatawan dan sikap industri.

Metode penelitian ini menggunakan metode kualitatif dengan pendekatan studi kasus, karena ada kondisi yang unik dan khusus di antara objek penelitian. Pengelola hotel yang berada di lingkungan mayoritas muslim di
Bandung, menganggap tidak utama berlabelkan "halal", karena sudah otomatis. Sedangkan bagi pengelola hotel di Bangkok, menganggap justru penting dan menguntungkan memiliki label "halal". Berangkat dari kondisi ini, tahapan penelitian awal mengkaji tentang persepsi pengelola industri hotel tentang wisata halal, oleh karena persepsi dibentuk oleh informasi yang menerpanya.Langkah kedua dalam menentukan komunikasi efektif, maka pemerintah perlu mendapatkan input dari masyarakat umum yaitu wisatawan dan industri, mengenai konsep halal yang mereka pahami, untuk selanjutnya menentukan karakter komunikator, media dan bentuk pesan yang tepat. Setelah menerapkan strategi komunikasi yang tepat, maka organisasi harus melakukan evaluasi terhadap proses, hasil dan konsekuensi kebijakan yang telah dilakukan (Sha, 2007). Untuk itu kerangka pikir penelitian ini terdapat pada gambar di bawah ini. 


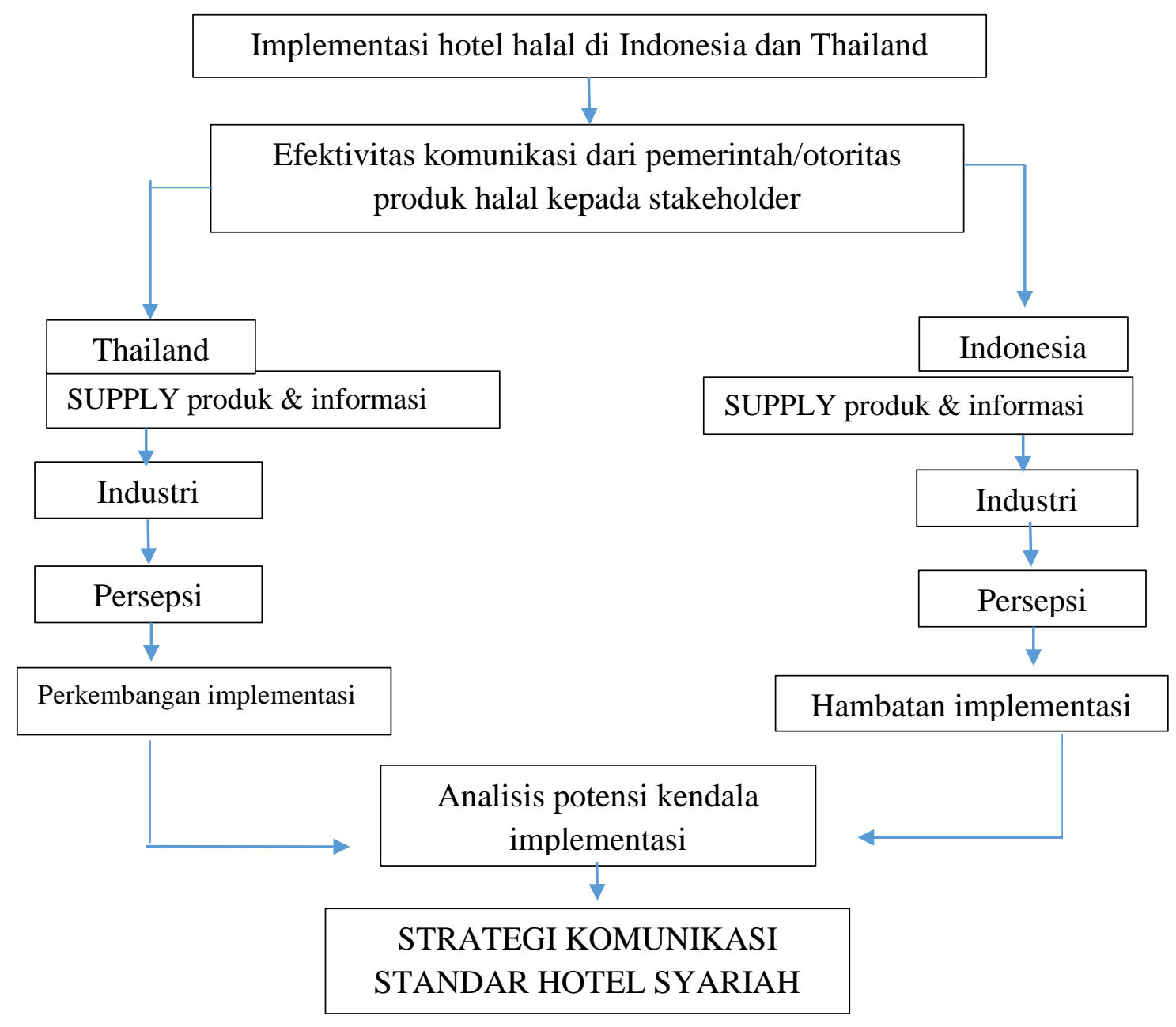

Gambar 3.1 Bagan Alur Penelitian

Penelitian ini dilakukan di dua

Kementerian Pariwisata dan Kota Bangkok, Thailand yang telah wilayah yaitu di Kota Bandung, Jawa Barat sebagai 1 dari 5 provinsi destinasi mengimplementasikan pariwisata halal. Adapun daftar hotel yang dituju sebagai halal prioritas yang ditargetkan oleh sampel terdapat pada tabel berikut.

Tabel 3. 1 Daftar Hotel Halal dan Hotel Konvensional Kota Bandung, Indonesia

\begin{tabular}{|l|l|l|l|l|}
\hline No & Nama Hotel & \multicolumn{1}{|c|}{ Bintang } & Status Hotel & \multicolumn{1}{c|}{ Lokasi } \\
\hline 1. & Noor Hotel & $\begin{array}{l}\text { Boutique } \\
\text { Hotel }\end{array}$ & Halal & Kota Bandung \\
\hline 2. & Ruby Hotel & $\begin{array}{l}\text { Hotel Bintang } \\
3\end{array}$ & Halal & Kota Bandung \\
\hline 3. & $\begin{array}{l}\text { Puteri Gunung } \\
\text { Hotel }\end{array}$ & $\begin{array}{l}\text { Hotel Bintang } \\
4\end{array}$ & Konvensional & Kota Bandung \\
\hline
\end{tabular}


Atie Rahmiatie, Rahma Fitria, Karim Suryadi, Rahmat Ceha, Strategi Komunikasi Pariwisata Halal...

\begin{tabular}{|l|l|l|l|l|}
\hline 4. & Luxton Hotel & $\begin{array}{l}\text { Hotel Bintang } \\
4\end{array}$ & Konvensional & Kota Bandung \\
\hline 5. & Alana Hotel & $\begin{array}{l}\text { Hotel Bintang } \\
4\end{array}$ & Konvensional & Kota Bogor \\
\hline 6. & $\begin{array}{l}\text { Grand Tjokro } \\
\text { Premiere Hotel }\end{array}$ & $\begin{array}{l}\text { Hotel Bintang } \\
4\end{array}$ & Konvensional & Kota Bandung \\
\hline
\end{tabular}

Sumber: Olah Data Peneliti 2019

Tabel 3. 3.Daftar Survey Hotel dan

Restaurant Halal Kota Bangkok,

Thailand

\begin{tabular}{|c|c|c|c|}
\hline No. & $\begin{array}{l}\text { Nama } \\
\text { Hotel }\end{array}$ & Bintang & Status \\
\hline 1. & $\begin{array}{l}\text { Nouvo } \\
\text { City Hotel }\end{array}$ & $\begin{array}{l}\text { Hotel } \\
\text { Bintang } 3\end{array}$ & $\begin{array}{l}\text { Hotel } \\
\text { Halal }\end{array}$ \\
\hline 2. & $\begin{array}{l}\text { Blue } \\
\text { Elephant } \\
\text { Restaurant }\end{array}$ & $\begin{array}{l}\text { Fine } \\
\text { dinning } \\
\text { restaurant }\end{array}$ & Restaurant \\
\hline 3. & $\begin{array}{l}\text { Al Meroz } \\
\text { Hotel }\end{array}$ & $\begin{array}{l}\text { Hotel } \\
\text { Bintang } 4\end{array}$ & $\begin{array}{l}\text { Hotel } \\
\text { Halal }\end{array}$ \\
\hline 4. & $\begin{array}{l}\text { Amari } \\
\text { Water }\end{array}$ & $\begin{array}{l}\text { Hotel } \\
\text { Bintang } 5\end{array}$ & $\begin{array}{l}\text { moslem } \\
\text { friendly }\end{array}$ \\
\hline
\end{tabular}

(FGD) maka diuraikan temuan lapangan dalam tabel berikut.

Tabel 4.1.Preferensi Industri Terhadap Unsur Komunikasi

\begin{tabular}{|c|c|c|}
\hline \multirow{2}{*}{ Variable } & \multicolumn{2}{|c|}{ Preference } \\
\hline & Industri perhotelan Indonesia & Industri perhotelan Thailand \\
\hline $\begin{array}{c}\text { Perception of } \\
\text { Halal Hotel }\end{array}$ & $\begin{array}{l}\text { a.Value of quality dari hotel halal } \\
\text { diakui dapat membangun tata nilai } \\
\text { masyarakat yang positif, namun } \\
\text { benefitnya tidak lebih unggul dari } \\
\text { hotel konvensional } \\
\text { b.Value of quality bervariasi. } \\
\text { Setiap pemilik hotel memiliki } \\
\text { standar halal tersendiri terhadap } \\
\text { implementasi saran fisik dan jasa/ } \\
\text { pelayanan (memiliki pedoman } \\
\text { tersendiri karena aliran yang } \\
\text { dianut beragam). } \\
\text { c.Value of money hotel halal masih } \\
\text { rendah, karena biaya operasional } \\
\text { yang tinggi dan permintaan yang } \\
\text { rendah }\end{array}$ & $\begin{array}{l}\text { a.Value of quality halal hotel di } \\
\text { Thailand didasari oleh prinsip } \\
\text { Islam yang universal, sehingga } \\
\text { dapat diterima oleh semua } \\
\text { kalangan. } \\
\text { b.Value of quality diperkuat dengan } \\
\text { sertifikasi sebagai jaminan } \\
\text { kemanan dan kehalalan produk. } \\
\text { c.Value of money hotel halal cukup } \\
\text { tinggi, karena permintaan } \\
\text { wisatawan muslim yang tinggi } \\
\text { terhadap halal hotel. } \\
\text { d.Value of emotional bagi pemilik } \\
\text { halal hotel, sangat tinggi, tidak bisa } \\
\text { dibandingkan dengan materi. Bagi } \\
\text { pemilik hotel konvensional, }\end{array}$ \\
\hline
\end{tabular}

Online ISSN : 2540-8402 | Print ISSN : 2540-8399 


\begin{tabular}{|c|c|c|}
\hline & $\begin{array}{l}\text { d.Value of emotional bagi pemilik } \\
\text { halal hotel, sangat tinggi, tidak } \\
\text { bisa dibandingkan dengan materi. } \\
\text { Namun bagi pemilik hotel } \\
\text { konvensional, nilainya tidak } \\
\text { menguntungkan } \\
\text { e.Inovasi produk hotel halal belum } \\
\text { maksimal, sehingga wisatawan } \\
\text { belum merasakan benefit materi } \\
\text { yang lebih unggul dari hotel } \\
\text { konvensional. }\end{array}$ & $\begin{array}{l}\text { nilainya juga cukup baik, karena } \\
\text { menjadi diferensiasi dalam menarik } \\
\text { minat wisatawan muslim di negara } \\
\text { non muslim. } \\
\text { e.Inovasi produk hotel halal } \\
\text { dimaksimalkan melalui berbagai } \\
\text { program unggulan dan harga yang } \\
\text { bersaing. }\end{array}$ \\
\hline $\begin{array}{c}\text { Interest to } \\
\text { Implement } \\
\text { Sharia Hotel } \\
\text { Standard }\end{array}$ & $\begin{array}{l}\text { a.Minat pemerintah sangat tinggi } \\
\text { terhadap pengembangan wisata } \\
\text { halal Indonesia } \\
\text { b.Industri hotel konvensional } \\
\text { belum tertarik dengan brand hotel } \\
\text { halal } \\
\text { c.Minat wisatawan masih rendah } \\
\text { terhadap hotel halal }\end{array}$ & $\begin{array}{l}\text { a.Minat pemerintah sangat tinggi } \\
\text { dalam mengembangkan Thailand } \\
\text { sebagai muslim friendly destination } \\
\text { b.Industri hotel konvensional mulai } \\
\text { tertarik dengan brand muslim } \\
\text { friendly } \\
\text { c.Minat wisatawan cukup tinggi } \\
\text { terhadap brand hotel halal di } \\
\text { negara non muslim }\end{array}$ \\
\hline
\end{tabular}

Sumber: Hasil Olah Data Peneliti 2019

Persepsi industri terhadap product value hotel halal, sejauh ini terbentuk bukan hanya dipengaruhi oleh faktor komunikasi yang dilakukan oleh pemerintah, namun lebih kuat dipengaruhi oleh 1) Target utama pendirian hotel (intrinsic), serta faktor exstrinsic yaitu 2) Demand (permintaan wisatawan) dan 3) Cost (biaya) yang harus ditanggung. Ketiga komponen inilah yang seharusnya dijadikan target sasaran komunikasi oleh pemerintah. Pengelola hotel halal mendirikan dan mengelola hotel halal berdasarkan ideologi dan paham yang dianut dan juga fokusnya pada penyebaran agama, disamping keinginan untuk berbisnis. Sedangkan hotel konvensional benarbenar menjalankan dan mengelola hotel yang didasari pada bisnis. Dengan tingginya minat berwisata dari wisatawan muslim di Bangkok, para pengelola bisnis pariwisata khususnya perhotelan banyak yang berinisiatif untuk menerapkan prinsip halal di hotelnya. Berbeda dengan di Indonesia, sebagai negara dengan mayoritas muslim, maka standar dasar halal dianggap sudah menyatu dalam kehidupan masyarakatnya, termasuk industri. Sehingga tidak dirasakan urgent untuk menerapkan dan memfokukan pada branding halal hotel.

\section{Komparasi Kebijakan Pariwisata Halal Indonesia dan Thailand}

Dalam konteks produk halal, pemerintah Indonesia memiliki Undang Undang No. 33 Tahun 2014 yang menjelaskan kewajiban pemerintah dalam memberikan jaminan konsumen tentang produk yang beredar di pasaran dan amanat untuk membentuk Badan Pusat Jaminan Produk Halal (BPJPH). Dengan adanya UU ini tentunya membantu 
pengembangan pariwisata halal di Indonesia dengan memberikan wisatawan kenyamanan dan kepercayaan atas produk yang dikonsumsinya.

$\begin{array}{rcc}\text { Sejalan } & \text { dengan } & \text { keseriusan } \\ \text { pengembangan } & \text { pariwisata } & \text { halal di }\end{array}$
Indonesia, pada tahun 2014 pemerintah melalui Kementerian Pariwisata dan Ekonomi Kreatif menerbitkan Peraturan Menteri No. 2 Tahun 2014 terkait Pedoman Penyelenggaraan Usaha Hotel Syariah. Dalam peraturan ini diatur standar penyelenggaraan usaha akomodasi syariah yang digolongkan menjadi dua kategori yaitu, Hilal 1 yang merupakan standar minimal hotel syariah dan Hilai 2 yang sudah memenuhi seluruh ketentuan hotel syariah. Namun, peraturan menteri ini dicabut dengan terbitnya Peraturan Menteri No. 11 Tahun 2016. Jika ditinjau kembali, saat ini tidak terdapat regulasi yang dikeluarkan oleh pemerintah terkait dengan pengembangan pariwisata halal di Indonesia. Tentunya pengembangan pariwisata halal akan lebih optimal jika memiliki regulasi yang mengaturnya. Melihat banyak sekali instrumen terlibat yang perlu diperhatikan dalam pariwisata halal seperti destinasi wisata halal, jasa atau biro perjalanan wisata halal, akomodasi halal, restoran halal, dan lain-lain.

Melihat kondisi tidak adanya peraturan terkait pariwisata halal, Dewan Syariah Nasional, Majelis Ulama Indonesia (DSN-MUI) pada tahun 2016 mengeluarkan fatwa yang mengatur penyelenggaraan pariwisata syariah dalam Fatwa No. 108/DSN-MUI/X/2016. Fatwa ini berisikan pedoman yang membahas tentang keseluruhan kegiatan pariwisata syariah, mulai dari ketentuan akad (perjanjian) yang dilakukan, ketentuan hotel syariah, destinasi wisata syariah, SPA, sauna, biro perjalanan syariah, dan juga pemandu wisatanya. Namun, dalam penelitian (Al Hasan, 2017) dijelaskan bahwa fatwa ini memiliki beberapa kekurangan karena ditemukan ketentuan-ketentuan yang harus didiskusikan kembali. Beberapa ketentuan dinilai dapat mengirim perkembangan pariwisata halal ke arah yang eksklusif. Sedangkan, pariwisata halal sebaiknya masih bersifat universal, tidak hanya diperuntukan bagi muslim saja melainkan kepada semua wisatawan, baik itu muslim ataupun non muslim. Lebih lanjut, ditemukan juga beberapa ketentuan dalam fatwa yang dapat menimbulkan multitafsir dalam memahaminya.

Meskipun tidak ada peraturan resmi yang dikeluarkan oleh pemerintah pusat. Namun, bagi daerah tertentu yang menjadikan pariwisata halal sebagai fokus pembangunannya, mereka mengatur kebijakan pariwisata halal ini melalui peraturan daerah. Hal ini dilakukan di Nusa Tenggara Barat, dimana pemerintah daerah mengeluarkan Peraturan Daerah (Perda) No. 2 Tahun 2016 dan Peraturan Gubernur No. 51 Tahun 2015. Peraturan terkait pariwisata halal tersebut menjelaskan secara detail terkait pihak-pihak, indsutri dan unsurunsur dalam pengembangan pariwisata halal di NTB. Akan lebih baik jika terdapat suatu kebijakan resmi yang dikeluarkan oleh pemerintah dalam mendukung pembangunan pariwisata halal di Indonesia. Sehingga, setiap stakeholder yang bergerak dalam pariwisata halal memiliki suatu acuan yang jelas. 
Thailand sendiri memiliki 7.000.000 populasi muslim. Hal ini berdampak pada permintaan pada produk makanan halal yang besar di Thailand. Sertifikasi halal pertama kali dijalankan pada tahun 1948 tetapi akibat beberapa kesulitan teknis dalam prosesnya sehingga tidak dilanjutkan. Namun, saat ini Thailand sudah memiliki komoditas produk halal yang legal. Sertifikasi halal dijalankan oleh Halal Standard Institute of Thailand (Nurdiansyah, 2018). Dengan kondisi tersebut tentunya membantu pemerintah Thailand dalam menjamin kebutuhan wisatawan muslim saat berkunjung ke Thailand.

Kementerian Pariwisata dan Olahraga Thailand bekerja sama dengan Institut Standarisasi Halal Thailand dalam merilis Halal Food Standard Certification untuk toko makanan, restoran, dan hotel. Sertifikasi halal di Thailand sendiri dikeluarkan oleh The Central Islamic Committee. Selain itu, untuk mendukung keberlangsungan industri pariwisata halal, pemerintah Thailand melalui Kementerian Pariwisata dan Olahraga mengeluarkan Halal Food Services for Tourism. Halal Food Services for Tourism ini merupakan pedoman yang mengatur standar makanan halal untuk keperluan pariwisata. Dalam pedoman ini, terdapat beberapa komponen yang dinilai diantaranya lokasi, bahan baku, managemen area dalam persiapan makanan dan pelayanan, wadah atau peralatan, personil, pembuangan air, keamanan, pelayanan, tanggung jawab sosial, managemen

Tabel 4. 1 Perbandingan Product Value pada hotel halal dan non halal di Indonesia dan Thailand lingkungan dan hubungan sosial. Dari setiap komponen yang ada terdapat turunan indikatornya masing-masing.

Dengan adanya kebijakan ini, memperlihatkan kesiapan Thailand dalam menyambut wisatawan muslim. Lebih lanjut, adanya pedoman ini membantu industri-industri yang bergerak dalam pariwisata halal lebih terarah dan terintegrasi. Dengan adanya pedoman yang dijalankan pun memberikan nilai lebih seperti kepercayaan dan jaminan kepada wisatawan muslim.Pariwisata dengan sifatnya yang multidisiplin dan lintas sektoral tentunya membutuhkan keterlibatan semua pihak dalam pengembangannya. Pertimbangan keterkaitan antar sektor dan penanganan pariwisata semakin rumit dalam pengembangan suatu destinasi yang terpadu. Oleh karena itu, dalam pembangunan dan pengembangannya dibutuhkan sebuah kebijakan sebagai alat bantu yang strategis. Kebijakan sendiri ialah serangkaian kegiatan/tindakan yang diusulkan sesorang, kelompok atau pemerintah agar dapat mencapai tujuan yang dimaksud (Suardana, 2013). Sedangkan Gee (Suardana, 2013) menjelaskan bahwa formulasi kebijakan pariwisata merupakan tanggung jawab pemerintah yang ingin mengembangkan atau mempertahankan pariwisata sebagai bagian yang integral dalam perekonomian. Dalam kasus pariwisata halal pun kebijakan sangat diperlukan untuk mewujudkan tujuan dan strategi dalam pembangunannya. 


\begin{tabular}{|c|c|c|c|c|}
\hline \multirow[b]{2}{*}{$\begin{array}{l}\text { Halal concept } \\
\text { perception according } \\
\text { to management of: }\end{array}$} & \multirow[b]{2}{*}{$\begin{array}{l}\text { Conventional } \\
\text { hotel }\end{array}$} & \multirow[b]{2}{*}{ Halal hotel } & \multicolumn{2}{|l|}{ country) } \\
\hline & & & $\begin{array}{l}\text { Conventional } \\
\text { hotel }\end{array}$ & Halal hotel \\
\hline 1.Value of quality & $\begin{array}{l}\text { Tourist } \\
\text { satisfaction }\end{array}$ & $\begin{array}{l}\text { God's } \\
\text { preference }\end{array}$ & $\begin{array}{l}\text { Tourist } \\
\text { satisfaction }\end{array}$ & $\begin{array}{l}\text { God's } \\
\text { preference }\end{array}$ \\
\hline 2.Value of money & Low & Low & $\begin{array}{l}\text { Moderate- } \\
\text { High }\end{array}$ & Low \\
\hline 3.Value of emotional & Low & High & High & High \\
\hline 2.Main target & $\begin{array}{l}\text { Value of } \\
\text { money }\end{array}$ & $\begin{array}{l}\text { Value of } \\
\text { emotional }\end{array}$ & $\begin{array}{l}\text { Value of } \\
\text { money }\end{array}$ & $\begin{array}{l}\text { Value of } \\
\text { emotional }\end{array}$ \\
\hline $\begin{array}{l}\text { 3.Prospek } \\
\text { perkembangan hotel } \\
\text { halal } \\
\end{array}$ & \multicolumn{2}{|l|}{ Stagnant } & \multicolumn{2}{|l|}{ High } \\
\hline $\begin{array}{l}\text { 4.Communication } \\
\text { strategies }\end{array}$ & \multicolumn{2}{|c|}{$\begin{array}{l}\text { - Need government support } \\
\text { to gain more profit } \\
\text { - Education and socialization } \\
\text { for moslem tourists }\end{array}$} & \multicolumn{2}{|c|}{ Halal brand promotion } \\
\hline
\end{tabular}

Sumber: Hasil Olah Data Peneliti 2019

Pariwisata dengan sifatnya yang multidisiplin dan lintas sektoral tentunya membutuhkan keterlibatan semua pihak dalam pengembangannya. Pertimbangan keterkaitan antar sektor dan penanganan pariwisata semakin rumit dalam pengembangan suatu destinasi yang terpadu. Oleh karena itu, dalam pembangunan dan pengembangannya dibutuhkan sebuah kebijakan sebagai alat bantu yang strategis. Kebijakan sendiri ialah serangkaian kegiatan/tindakan yang diusulkan seseorang, kelompok atau pemerintah agar dapat mencapai tujuan yang dimaksud (Suardana, 2013). Sedangkan Gee (Suardana, 2013) menjelaskan bahwa formulasi kebijakan pariwisata merupakan tanggung jawab pemerintah yang ingin mengembangkan atau mempertahankan pariwisata sebagai bagian yang integral dalam perekonomian. Dalam kasus pariwisata halal pun kebijakan sangat diperlukan untuk mewujudkan tujuan dan strategi dalam pembangunannya.

Kedudukan sektor pariwisata sebagai penyumbang devisa bagi negara dan sebagai sektor unggulan pembangunan nasional menjadikan pemerintah turut konsisten dalam pembangunan dan pengembangannya. Hal tersebut berdampak kepada kinerja pemerintah melalui kementerian pariwisata untuk terus mempromosikan Indonesia sebagai destinasi unggulan. Upaya tersebut dilakukan dalam rangka mendatangkan wisatawan baik nusantara maupun mancanegara. Citra pariwisata Indonesia di mata dunia serta perolehan prestasi dalam kompetisi internasional pun turut berkontribusi dalam menarik kunjungan wisatawan.

Indonesia sebagai destinasi pariwisata halal telah dikenal sebagai negara yang memberikan kemudahan bagi kebutuhan 
wisatawan muslim. Selain itu, potensi wisata alam dan budaya yang beragam, kemudahan pengurusan visa dan juga harga saing yang kompetitif pun menjadi pendukung untuk menarik wisatawan muslim berkunjung ke Indonesia. Kemudahan tersebut berdampak kepada jumlah kunjungan wisatawan muslim yang konsisten mengalami kenaikan setiap tahunnya. Hasil penelitian menunjukkan bahwa komunikasi memegang peranan penting dalam memperkuat product value dari pariwisata halal. Pemerintah sebagai komunikator utama, memiliki peran untuk menyosialisasikan secara konkrit aspek benefit dan manfaat dari implementasi hotel halal. Selain itu pemerintah juga perlu memiliki strategi komunikasi yang khusus, dalam menyosialisasikan keunggulan pariwisata halal kepada wisatawan. Karena pada dasarnya respon industri sangat ditentukan oleh permintaan (demand) dari wisatawan. Berikut digambarkan model strategi komunikasi pariwisata.

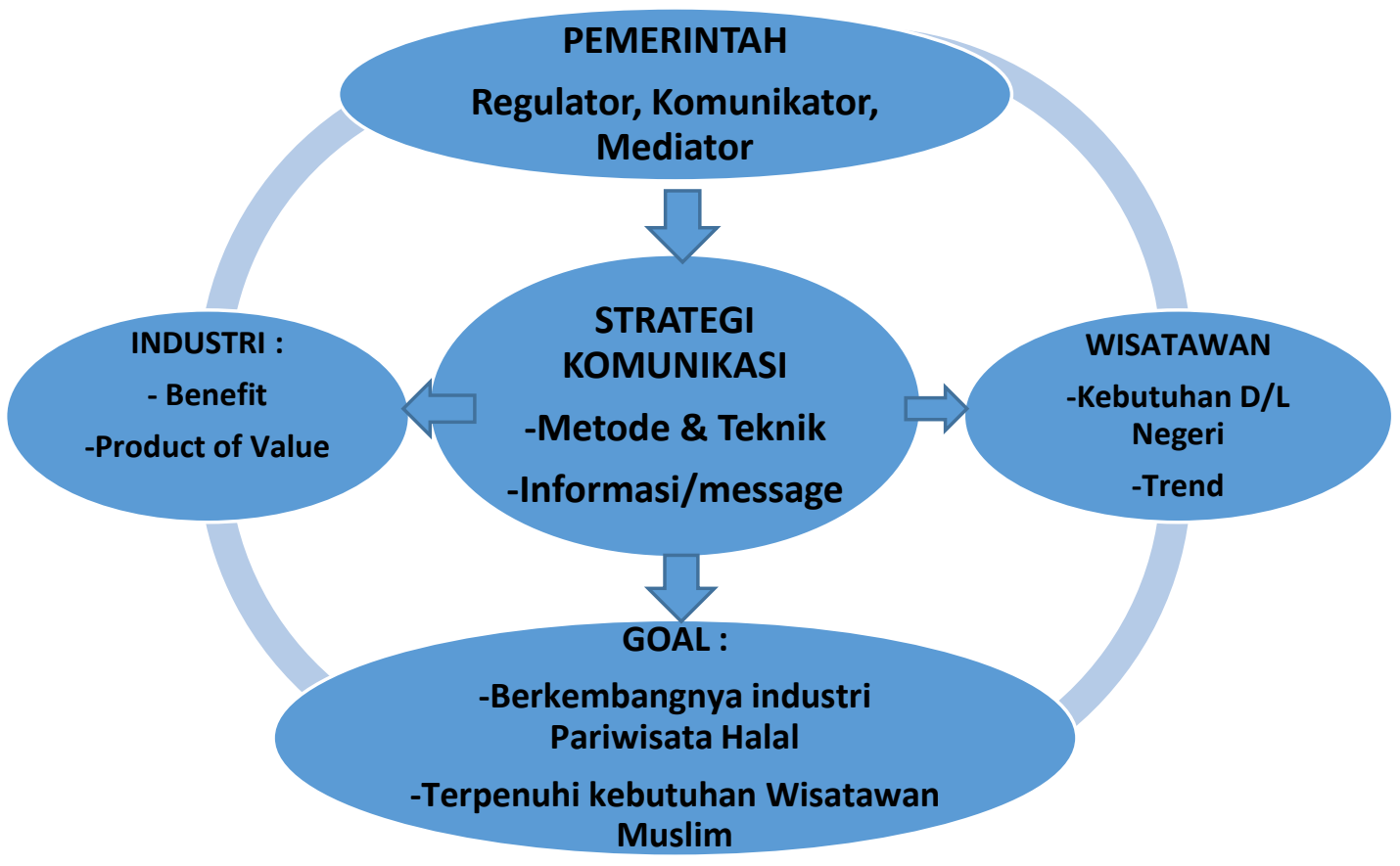

Sumber : Olahan peneliti (2019)

Secara ideal strategi komunikasi ideal dapat dibangun melalui optimalisasi fungsi komunikator pemerintah kepada industri dan wisatawan. Pemerintah bertanggung jawab untuk memberikan informasi dan kemudahan kepada industri halal hotel agar dapat bertahan dan mengembangkan produknya di tengah segala hambatan dan keterbatasan. Pemerintah juga dapat memperkuat value of emotional dari pengelola hotel halal, melalui sosialisasi benefit dan manfaat implementasi halal hotel. Disisi lain, profit merupakan tujuan utama dari bisnis. Maka kesesuaian antara kepentingan dan kebutuhan wisatawan, industri menjadi mutlak dibangun oleh 
Atie Rahmiatie, Rahma Fitria, Karim Suryadi, Rahmat Ceha, Strategi Komunikasi Pariwisata Halal...

pemerintah. Untuk itu pemerintah memiliki kewajiban untuk menyosialisasikan nilai kualitas halal hotel kepada wisatawan, mengedukasi mereka agar minatnya meningkat. Dari sini pemerintah memiliki fungsi sebagai mediator, yang memperkuat komunikasi wisatawan dengan pengelola hotel halal, sehingga value of money dari brand halal hotel dirasakan menarik bagi industri.

\section{Simpulan}

Persepsi dan minat wisatawan domestic tentang konsep hotel syariah, terbentuk oleh adanya komunikasi dan informasi dari pemerintah, terutama dalam memperkuat product value dari pariwisata halal. Pemerintah sebagai komunikator utama, memiliki peran untuk menyosialisasikan secara konkrit aspek benefit dan manfaat dari implementasi hotel halal. Implementasi industri terhadap product value hotel halal, sejauh ini dilatarbelakangi oleh 1) Target utama pendirian hotel (intrinsic), serta faktor exstrinsic yaitu 2) Demand (permintaan wisatawan) dan 3) Cost (Biaya) yang harus ditanggung. Pemilik hotel halal mendirikan dan mengelola hotel halal berdasarkan ideologi dan paham yang dianut dan juga fokusnya pada penyebaran agama, disamping keinginan untuk berbisnis. Sedangkan hotel konvensional benar-benar menjalankan dan mengelola hotel yang didasari pada bisnis. Dengan tingginya minat berwisata dari wisatawan-wisatawan muslim di Bangkok, para pengelola bisnis pariwisata khususnya perhotelan banyak yang berinisiatif untuk menerapkan prinsip halal di hotelnya. Berbeda dengan di Indonesia, sebagai negara dengan mayoritas muslim, maka standar dasar halal dianggap sudah menyatu dalam kehidupan masyarakatnya, termasuk industri. Sehingga tidak dirasakan urgent untuk menerapkan dan memfokuskan pada branding halal hotel.

Faktor yang menjadi penghambat implementasi konsep hotel syariah bagi industri, adalah rendahnya sosialisasi sertifikasi hotel syariah dan dinilai sebagai biaya tambahan yang cukup memberatkan. Diperlukan strategi komunikasi khusus, yang melibatkan semua komponen komunikasi yaitu komunikator, pesan dan penyajian serta media dalam intensitas yang tinggi,terutama promosi untuk menyosialisasikan keunggulan pariwisata halal kepada wisatawan. Karena pada dasarnya respon industri sangat ditentukan oleh permintaan (demand) dari wisatawan.

\section{Referensi}

Akyol, M., \& KILINÇ, Ö. (2014). INTERNET AND HALAL TOURISM MARKETING. Electronic Turkish Studies, International Periodical For The Languages, Literature and History of Turkish, 9/8(February), 171-186.

Amadeus Traveller Trend Observatory. (2016). Halal Travellers 2016. In Amadeus-commissioned report conducted by Context Consulting (pp. 1-21). Madrid.

Ambali, A.R. and Bakar, A.N. (2013) 'Halāl food and products in Malaysia: people's awareness and policy implications', Intellectual Discourse, Vol. 21, No. 1, pp.732.

Andriani, D., Khalikal, K. A., Aqmarina, L., Nurhayati, T., Permanasari, I. K., Binarwan, R., Anggraini, A. P. T. (2015). Laporan Akhir Kajian 
Pengembangan Wisata Syariah. Laporan Akhir Kajian Pengembangan Wisata Syariah, (Syariah Tourism), 1-201.

Ayob, N. M., \& Masron, T. (2014). Issues of Safety and Security: New Challenging to Malaysia Tourism Industry. $\quad 4$ th International Conference on Tourism Research (4ICTR), 12(SHS Web of Conferences), 1-10. http://doi.org/10.1051/shsconf/20141 201083

Bozorgaghideh, N. (2015). Halal tourism in kerala. International Journal of Management (IJM), IAME Publication, 6(8), 42-48.

Cancel, A. E., Cameron, G. T., Sallot, L. M., \& Mitrook, M. A. (1997). It depends: A contingency theory of accommodation in public relations. Journal of Public Relations Research, 9(1), 31-63. doi:10.1207/s1532754xjprr0901_0 2

Chen, C., Chen, S., Lee, H., \& Tsai, T. (2016). Ocean \& Coastal Management Exploring destination resources and competitiveness e A comparative analysis of tourists $\hat{\mathrm{a}} €^{\mathrm{TM}}$ perceptions and satisfaction toward an island of. Ocean and Coastal Management, 119, 58-67. https://doi.org/10.1016/j.ocecoaman .2015 .09 .013

Dallen, Timothy, J. (n.d.). Tourism and Islam: Consideration of culture and duty. Routledge Taylor \& Francis Group.Djaelani, A. R. (2013). Teknik pengumpulan data dalam penelitian kualitatif. Majalah Ilmiah Pawiyatan, XX, 82-92.

Hallahan, K., Holtzhausen, D., Van Ruler, B., Verčič, D., \& Sriramesh, K. (2007). Defining strategic communication. International Journal of Strategic Communication, 1(1), 3-35. doi:10.1080/15531180701285244

Harrigan, P., Evers, U., Miles, M., \&
Daly, T. (2017). Customer engagement with tourism social media brands. Tourism Management, 59, 597-609. https://doi.org/10.1016/j.tourman.20 16.09.015

Holtzhausen, D., \& Zerfass, A. (2015). Strategic communication: Opportunities and challenges of the research area. InD. R. Holtzhausen, \& A. Zerfass (Eds.), The Routledge handbook of strategic communication (pp. 317). New York,NY: Routledge.

Iravani, M. R., \& Mozaffari, A. M. (2013). Review The Status of Tourism from the Perspective of The Qur â $€^{\mathrm{TM}}$ an. International Journal of Basics and Applied Sciences, 1(3), 628-633.

Kim, K.I., Syamil, A. and Bhatt, B.J. (2007) 'A resource-based theory of supplier strategy', International Journal of Logistics Systems and Management, Vol. 3, No. 1, pp.20-33.

Krech, David, Crutchfield, Richard S., \& Ballachey, Egerton L., (1962), Individual in Society: A Textbook of Social Psychology, McGraw Hill, Kogakusha, Ltd.

Mastercard, B. (2016). MasterCardCrescent Rating Global Muslim Travel Index 2016 Global Muslim Travel Index 2016, (March).

Nirwandar, S. (2012). Kata Sambutan Wakil Menteri Pariwisata Ekonomi Kreatif. In Prospek Bisnis Pariwisata Syariah (I, pp. vii-viii). Jakarta: Buku Republika.

Pandian V. K. M. (2013). Handbook of Research on Holistic Optimization Techniques in the Hospitality, Tourism and Travel Industry. In Business Science Reference (an imprint of IGI Global) (Vol. 53, pp. 1-199). Malaysia: IGI-GOBAL. http://doi.org/10.1017/CBO9781107 415324.004

Pitana, G. dan I. G. (2005). Sosiologi 
Atie Rahmiatie, Rahma Fitria, Karim Suryadi, Rahmat Ceha, Strategi Komunikasi Pariwisata Halal...

Pariwisata. In Andi Offset. Yogyakarta.

Raj, R. and Griffin, K. (Ed.). (2015). Religious Tourism and Pilgrimage Management: An International Perspective. Dylunio Cymru (2nd ed.). Oxfordshire \& Boston: CAB International.

Results, N., Utama, R., Bagus, G., Dhyana, U., Bali, P., Development, T. H. E., Bagus, G. (2015). Pariwisata Menurut Pandangan Islam dan Muslim.

Sweeney JC, Soutar GN, Johnson LW. 1999. The role of perceived risk in the quality - value relationship: a study in a retail environment. Journal of Retailing 75(1): 77105.

Sha, B. L. (2007). Dimensions of public relations: Moving beyond traditional public relations models. In S. C. Duhé(Ed.), New media and public relations (pp. 325). New York, NY: Peter Lang.

Shafie dan Othman. (2006). Barriers to Halal logistics operation: views from

Malaysian logistics experts. Int. Journal. Logistics Systems and Management, Vol. 22, No. 2.

Shakiry, A. S. (2009). Islamic tourism means tourism based on ethical codes. The International Conference on Tourism of Islamic Countries.

Stephen, P. Robbins, J. T. (2015). Perilaku Organisasi (Organizational
Behavior). In Jakarta: SalembaEmpat.

Sucipto, Hery; Andayani, F. (2014). Wisata Syariah: Karakter, Potensi, Prospek dan Tantangannya (I). Jakarta: Grafindo Books Media \& Wisata Syariah Consulting.

Suherlan, A. (2015). PERSEPSI MASYARAKAT JAKARTA TERHADAP ISLAMIC. The Journal of Tauhidinomics, 1(1), 6172.

Thalib, M.S., Hamid, A.B., Zulfakar, M.H., Chin, T.A. (2015). Barriers to Halal logistics operation: views from Malaysian logistics experts. Int. Journal. Logistics Systems and Management, Vol. 22, No. 2.

Wilson, J.A. and Liu, J. (2011) 'The challenges of Islamic branding: navigating emotions and halal', Journal of Islamic Marketing, Vol. 2, No. 1, pp.28-42.

Wonneberger,A., dan Jacobs,S. (2016). Mass Media Orientation and External

Communication Strategies: Exploring Organisational Differences, International Journal of Strategic Communication, DOI: 10.1080/1553118X.2016.1204613

Suardana, I. W. (2013). Analisis Kebijakan Pengembangan Pariwisata (Intervensi Melalui Kebijakan Pariwisata Berkelanjutan di Bali). 